\title{
Maria Lissowska'
}

\section{Crowdfunding - the Interplay between Evolving Organization and Embedding Institutions}

${ }^{1}$ Warsaw School of Economics, Warsaw, Poland, European Commission, Brussels, Belgium, E-mail: lisso@sgh.waw.pl

\begin{abstract}
:
This paper explains the functioning of economic crowdfunding (equity- and loan-based). One of the angles from which crowdfunding can be analysed is institutional economics. Namely, it can be studied as a case where the spontaneous evolution of contractual forms is difficult and the need for legislative intervention arises. The paper explains the divergence of interests and risks of three groups of agents involved (platforms, fundraisers and funders). The radical asymmetry of power, to the advantage of the platform, is inherent in this type of business.

The spontaneous development of strategies by the platforms (pricing and some non-price strategies relating to fundraisers) and recent developments in the direction of automatic decisions taken by the platform instead of funders, promotes the development of the crowdfunding business, but it does not ensure protection from risk of other parties. Still, the major source of risk for funders and partly also for fundraisers is the absence of liability of the platforms themselves. In these conditions, the spontaneous move towards the better alignment of the interests of parties seems unfeasible and external regulation is necessary.
\end{abstract}

Keywords: crowdfunding, two-sided markets, asymmetry of information, institutional arrangements

JEL classification: D02, D82, D85, G23

DOI: 10.1515/ael-2017-0032

\section{Table of Contents}

1 Introduction

2 Crowdfunding - a platform between funders and fundraisers

3 Size and structure of crowdfunding business in europe

4 Business models and practices of the crowdfunding platforms

5 Risks for investors and platforms

6 Crowdfunding from the perspective of fundraisers

7 Regulation of crowdfunding

7.1 Problems to be solved by regulation

7.2 Existing national legislation

7.3 Possible use of existing EU legislation

7.4 Need for further regulation of crowdfunding

8 Conclusion

References

Maria Lissowska is the corresponding author.

(c) 2018 Walter de Gruyter $\mathrm{GmbH}$, Berlin/Boston.

This content is free. 


\section{Introduction}

Crowdfunding is a method of organizing the transfer of funds between funders and fundraisers, enabled by a platform. This kind of arrangement is a specific version of two-sided markets (according to the theory developed by Tirole). However, the crowdfunding business developed in particular directions. Relying on the Internet and exploiting sophisticated methods of data analysis to create portfolios for funders, crowdfunding platforms slowly took an active and not only an enabling role, going as far as replacing funders in their decisions. Thus, besides network effects and economy of search costs, a strong asymmetry of information and of decision making power between platform and participants emerges, making a platform similar to a bank or an investment firm, without being regulated like them. The paper focuses on the divergence of interests and risks between the three types of participants (funders, fundraisers and platforms). I will then assess the suitability of private arrangements designed by platforms from the point of view of protecting participants and of ensuring the viability of platforms themselves. On this basis, I will identify the needs for more formal rules which are spelled out by stakeholders.

Up to now platforms have tried to escape legislation even though it applied to them in part. For example, as platforms transfer money between funders and fundraisers, but do not wish to be supervised as payment institutions, they sub-contract payment activity to a third party. Similarly, equity-based platforms which do not wish to respect regulation for investment intermediaries, pretend not to execute investors' orders, but only communicate their "expression of interest".

However, the growing activity of crowdfunding platforms raises demands for specific institutions. This stems from investors conscious of risks they are subject to (often for decisions taken by the platform on their behalf) and also from platforms suffering from a reputation spoiled by the failures of their peers. This is an interesting case of the evolution of institutions. Due to asymmetry of power between the parties (fundraisers, funders and the platform) only the platform can propose any efficient rules of behavior. However, taking into account the interests of the platform (the necessity to grow fast, in a highly competitive environment) individual platforms may either not be interested or unable to propose rules better aligning their functioning with the needs of all participants while taking into account the divergence of interests between them. Thus, external regulation is necessary.

Legislation existing in some countries focuses on the security of funders supposing that they actively choose the projects funded. The requirements of funders' skills and of basic sound governance of platforms are typically proposed. This is also the content of the recently published proposal for the Regulation of crowdfunding by the European Commission. I will identify the need for regulation to go further, with among others the clearer distinction of decision making rights and responsibilities of all participants, including platforms.

My analysis will be limited to so-called economic crowdfunding, which means crowdlending and equitybased crowdfunding. I will not be dealing with other kinds of crowdfunding (like donations or reward-based crowdfunding) and I will take into account only the functioning of professional platforms, disregarding platforms run by individual fundraisers (such as artists or innovators). The territory of the European Union will be the limit of my factual analysis and similarly of the scope of existing and possible legislation.

\section{Crowdfunding - a platform between funders and fundraisers}

Crowdfunding (funding projects by a "crowd") is a manner of bringing together a large number of funders. The recipients of these funds are one beneficiary (as in the case of donations) or, typically, a number of potential users of funds. In crowdfunding an entity called the platform plays an essential role. This manner of organizing financial flows developed together with the Internet, as crowdfunding platforms use this tool extensively to raise money. Beside this technical reason, it is claimed that crowdfunding fills in the gaps in existing organizations of financial flows, for example enabling previously under-served needs to be fulfilled. It either substitutes or complements other means of financing (Oxera, 2015: 2). This was also one of the elements proposed in Autumn 2015 by the EU under the initiative of the Capital Markets Union, to facilitate the access of SMEs to finance.

Four theories are relevant for the analysis of crowdfunding:

- Two-sided markets

- Information asymmetry

- Behavioural finance (behavioural economics)

- Theory of institutional evolution. 
The organization of crowdfunding has some features of a two sided market (Martens, 2016; Rochet \& Tirole, 2004; Viotto, 2015). However, the role of platforms of different kinds intermediating in meetings of two types of users (buyers and sellers, funders and fundraisers/borrowers) should be underlined. Their involvement reduces transaction costs, which is a clear advantage for both types of users, who would otherwise have to spend time and money searching for partners for future transactions. There are also other outcomes of the activity of platforms. They induce the so called indirect network effects, one of which is the cross-group external effect (for example between the group of sellers and the group of buyers) meaning that an increasing number of clients on each side is beneficial to the other side (sellers benefit from the growing number of buyers, and buyers are better off if the number of sellers is large).

A platform is also a kernel of crowdfunding activity, enabling meeting the demand side (potential fundraisers) with the supply of funds side (investors). However, the business model of a crowdfunding platform differs from the typical "search and matching" platforms (like Google, Amazon, eBay, which enable one-to-one matching) and there are also different business models among crowdfunding platforms. Such a platform is an organization (or is managed by an organization), usually registered as a company, extensively (or sometimes exclusively) using software tools for communication with customers. It puts together a number of funders each of whom, individually, would in principle not be able to finance any project, and collects funds from them. It accepts different projects for funding and channels (or helps channel) funds to them. The result of matching is essentially many-to-many.

Besides cross-group external effects there are also within the group external effects of crowdfunding platforms (Belleflamme, Omrani \& Peitz, 2015: 15-19, 2016: 7-8). As for fundraisers, they compete between themselves for funding, so the effect is in principle negative. They can however profit from the experience of other fundraisers, under certain conditions. As for funders, they in principle draw profits from the large number of other funders, because of the increased probability that the chosen project will succeed in being funded. Positive (or negative) external effects can also emerge within groups of funders because of following the behavior of the others (for example "herding", or free-riding). The negative sides of these effects should be managed by the platform.

In the market for financial products (loans and equity) organized by crowdfunding there is strong information asymmetry between funders and fundraisers (Agrawal, Catalini \& Goldfarb, 2013: 20; Viotto, 2015: 44). This situation has already been studied for a long time in the context of relationships between lenders and borrowers (Stiglitz \& Weiss, 1992: 694-724; Mayer, 1994:113). On top of the inherent risks of a project, lenders (funders, in crowdfunding) are at a disadvantage with respect to borrowers (fundraisers) as they do not have access to information on all the particularities of the borrower's business and the projects to be funded and can even be, in some cases, subject to dishonesty in providing information by borrowers (Sharpe, 1990). Moreover, lenders are subject to agency problems, as they cannot easily monitor how the funds are spent. Information asymmetry and high ex-ante transaction costs are the source of financial intermediation (Bhattacharya \& Thakor, 1993). An additional reason for intermediation is the economy of ex-post costs of monitoring, which results in delegation to a specialized intermediary (Diamond, 1984).

Agrawal et al. (2013: 19-21) indicate that funders in crowdfunding can be exposed to particularly high risks. In crowdfunding, asymmetry of information is exacerbated because of the number and remoteness of funders. Asymmetry of information is also more detrimental for investors in crowdfunding due to their lack of knowledge and experience (Viotto, 2015: 44). Thus each of them, individually, has weak individual incentives to perform costly due diligence. This can result in a negative selection of projects, where the best of them would avoid crowdfunding, not expecting to get the correct price. Another risk for funders is a possible moral hazard on the side of the beneficiaries, who may fail to achieve the expected results due to their own weaknesses (of governance, of reporting) exacerbated by an absence of monitoring and of external advice which more traditional funders (banks, venture capital, business angels) usually provide.

In the case of banking intermediation, the bank may limit both negative selection and moral hazard by initial screening and further monitoring. Crowdfunding platforms may substitute funders in professional screening of projects ${ }^{1}$ according to their willingness as, contrary to banks, they are not parties to crowdfunding transactions. However, because of their exposure to risk, banks are usually ${ }^{2}$ rather risk averse, unwilling to fund smaller projects, which are either riskier or more expensive in terms of monitoring (Akiba \& Lissowska, 2006). Thus, crowdfunding is in principle more accessible to small business projects.

The third relevant theory in analysing crowdfunding is that of behavioural finance and, more generally, behavioural economics. As a matter of fact, funders (and also sometimes fundraisers) can be subject to different behavioural biases $^{3}$. Some can be over-optimistic about the results of a project or, on the contrary, excessively risk-averse. Not having abundant information about projects and not being able to analyse them sufficiently, funders may apply "rules of thumb" instead of rational calculation, or follow the decisions of other funders, either those who decided before them, or those considered more knowledgeable (Kim \& Viswanathan, 2016). As reported by Agrawal et al. (2013: 29) funders rely heavily on capital accumulated by a project as a signal of 
quality. This "herding" can be rational if the decisions of previous funders were based on credible information (Zhang \& Liu, 2012) but also irrational, when funders ignore information they have (Belleflamme, Omrani \& Peitz, 2015:32). In particular, the funders can be misled by false signals issued purposely by fundraisers and/or react emotionally with respect to the project. Reacting to the decisions of others can result in a positive correlation between decisions taken by the whole crowd at different moments of time (as in the case of herding, following the decisions of early funders), but also negative correlation (free-riding, avoidance of contributing to a project which has already received support assuming that someone else will complete the financing needed) (Belleflamme, Omrani \& Peitz, 2015: 30-33). These tendencies are contradictory, and it was found that they co-exist, so it is difficult to indicate a prevailing pattern.

Crowdfunding, like all business activities, is based on contracts and internal rules and is also impacted by institutional frameworks. According to the classification of Williamson (2000), the private rules (contracts and rules of governance) are at level three, below informal and formal rules of general application, to which they should be subordinated. This is a static approach and it will be shown in the following what the private rules applied by individual crowdfunding platforms are (to the degree they can be observed externally), what the formal rules potentially applicable to platforms are (in European and national legislation) and what the attitude of platforms to them is. In many cases, as the relationships between the players do not fall directly under sectoral European legislation, platforms prefer to escape it.

As for the dynamic aspect, many authors claim that the process of changing formal rules is endogenous, driven by the change of informal rules. This is the position of Hayek, and also of North (1995, 1997). North (1990: 83-91) describes the process of institutional change as driven by marginal adjustments in contractual relations to price changes, preferences, technology, relative costs, or taste. It is in principle assumed that the parties to contracts are equal ${ }^{4}$. However, North underlines that this process can be complicated by, for example, problems of power. As an example of the importance of power, existing organizations and lobbyists may pressure for the emergence of new formal rules, or for the preservation of existing ones, because the shape of formal rules impacts on their costs and benefits ${ }^{5}$.

Legal institutionalism underlines that only informal rules are insufficient for the functioning of modern societies and that enforcement by the State is necessary. Spontaneous bottom-up mechanisms based on the change of informal rules usually do not suffice for the emergence of formal rules of general application because this process of constituting new law requires the resolution of conflicts (Hodgson, 2009: 146; Deakin et al., 2017: 190-191).

Looking at the dynamics of legislative processes it is important not to overlook the importance of the games of interests of different stakeholders. The element of asymmetries of power and their reflection in the process of elaboration of formal rules is particularly underlined by the historical institutionalism described in (Hall \& Taylor, 1996). Also, the "functional" branch of Law and Economics (Parisi, 2004, 265-266) states that the preparation of a law is based on the game of interests and power ${ }^{6}$. This is particularly relevant for the regulation of businesses, such as crowdfunding.

Another problem studied by institutional economists is a possible conflict between (more traditional) informal rules and the formal rules which can be more easily introduced. According to Fiori (2002: 1039), conflict between informal and formal rules "stresses the role of contingencies in the process of institutional change: the more the rules conflict, the more contingencies can determine the result of the process, and the less the past (embodied in informal rules) is able to condition the direction of change." These contingencies played a particularly important role in the transition to the market economy making it rather path contingent than path dependent (Nielsen, 2006).

Institutional economists were working in particular on the process of privatization and deregulation. In this process, on one hand, interest groups played a prominent role, while other elements in the existing infrastructure of political decision making "veto points" stabilized it (Henisz \& Zelner, 2006). Another dynamic aspect of institutional change subject of the research of institutional economists was the process of overturning newly introduced rules. In the real world an opportunity for this research was offered by the examples of transition to the market economy in Eastern and Central Europe where, after some time, efforts to overturn some elements of private ownership and the freedom to do business took place (in particular in Hungary and in Poland e. g. Baltowski \& Kozarzewski, 2016; Szanyi, 2016;). A very insightful analysis, with numerous examples from different countries, of the whole process leading to the overturning of initial agreements with foreign investors is provided by Henisz and Zelner (2003). The authors indicate not only the role of interest groups and of their power, but also of the perception by the general population of the legitimacy of previous agreements with foreign investors and of the fairness of wealth distribution.

Within the broad scope of problems studied by institutional economics the principal-agent approach could be relevant to crowdfunding. This problem arises when a party (a principal) may make profits or suffer losses due to the performance of another party (agent) on its behalf and, due to asymmetry of information, the principal cannot be sure if the agent actually acts in his interest (Kasper \& Streit, 1998: 271 - 275). The potential moral 
hazard attitude of the agent was studied in different situations. The most straightforward is the case where an agent has contractual obligations to a principal (shareholders vs. managers, managers vs. workers). This approach was also applied to non-contractual situations (conflict between voters as principals and politicians as agents, described e. g. in Potrafke, 2013). Those situations differ as to the possibility of having control over agents. To enhance the results of agents, besides monitoring (if possible), the theory advises the application of adequate incentives to align the preferences of agents with those of principals (Jensen \& Meckling, 1976). The incentives may be financial rewards, but also pressure of competition on quality of work, or loyalty to a principal, or else reputation.

As to crowdfunding, it is interesting to identify the groups of stakeholders having clearly diverging interests (fundraisers, funders and platforms) and asymmetry of power between them ${ }^{7}$. The platform is one entity, while participants are many and usually can't negotiate contracts with the platform. Moreover, some organizational solutions (such as imposing upper thresholds on the participation of funders in equity of projects, to protect them against risk, or arranging contracts between funders and fundraisers on the basis of anonymity) deepen this asymmetry of power. Thus, it cannot be expected that private rules designed by the platform will adjust spontaneously to ensure the best outcome for all participants. Intervention by the legislator can be requested by some groups of participants, or pressure can arise in the name of public interest (such as financial stability).

\section{Size and structure of crowdfunding business in europe}

There are no official statistics on crowdfunding in Europe. Data come from different surveys of platforms, so necessarily the scope of analysis and reliability of data are questionable. In this paper I use the results of surveys carried out by the Cambridge Centre for Alternative Finance. This Centre has published the three following consecutive reports:

- Moving Mainstream (Wardrop et al., 2015)

- Sustaining Momentum (Zhang et al., 2016)

- Expanding Horizons (Ziegler et al., 2018).

Reports on crowdfunding in UK were published separately (the most recent, fourth report, is Entrenching Innovation, 2017).

The reliability of these reports comes from broad coverage (the latest report claims to cover $90 \%$ of European crowdfunding) and coherent methodology (Ziegler et al., 2018:16). The disadvantage is changing geographic scope (the latest report, of 2018, covers 45 countries, so exceeds the boundaries of the European Union) (Ziegler et al., 2018: 19). For this reason, the information on the size and growth of crowdfunding should be treated with caution. However, the reports of the Cambridge Centre for Alternative Finance provide reliable data on what interests me the most in this paper, namely the business models of crowdfunding.

All the data quoted in this section refer to the countries in the scope of 2018 Report of the Cambridge Centre for Alternative Finance and exclude UK, unless indicated otherwise.

The report published at the beginning of 2018 provides the data for 2016 (Ziegler et al., 2018: 21-25). The reported volume of crowdfunding amounts to $€ 7,671 \mathrm{~m}$ and, in the scope covered by the reports of the Cambridge Centre for Alternative Finance, its annual growth rate was $41 \%$ (as compared to $92 \%$ a year ago and $151 \%$ two years ago). UK-based platforms are the largest contributors with $73 \%$ of transactions (€5,608 m). However, the growth of crowdfunding in UK has recently been slower than in other European countries. In terms of size, the next countries are France, Germany, the Netherlands, Finland, Spain and Italy, with much smaller volumes of transactions ( $€ 444 \mathrm{~m}$ for France), but faster growth.

The most popular type of crowdfunding in Europe (excluding UK) is P2P Consumer Lending (34\%), followed by P2P Business Lending (17\%), Invoice Trading (12\%) and Equity Based Crowdfunding (11\%) (Ziegler et al., 2018: 29). These were also the lending-based crowdfunding platforms that have shown the fastest growth, while equity-based crowdfunding experienced slower growth.

The structure of crowdfunding in UK was different. There P2P lending to business prevails, closely followed by consumer lending and P2P property lending, the market volume of all the three being very similar. Growth of consumer and property lending outpaced that of business lending (Entrenching Innovation, 2017: 12-13). $72 \%$ of funding by all crowdfunding models, with debt-based dominating, was used by start-ups and SMEs (Entrenching Innovation, 2017: 18). It is estimated that in 2016 crowdlending constituted the equivalent of around $15 \%$ of new bank lending to small businesses in the UK (Entrenching Innovation, 2017: 21).

The 2018 report on European crowdfunding identified new types of economic crowdfunding, namely Real Estate Crowdfunding, P2P Property Lending (funding loans secured by property), Balance Sheet Business and 
Consumer Lending (loans provided directly by the platform), Debt Base Securities (buying bonds), Mini-Bonds and Profit Sharing. These new forms of crowdfunding constitute now less than $5 \%$ of the volume of transactions, but their structure (loans secured by property, fixed rate products, products involving the platform as lender) seem to signal more need of security from funders (Ziegler et al., 2018: 28).

The 2018 report, similarly to the previous one, points out the increasing proportion of institutional investors (pension funds, mutual funds, asset management firms, banks). These investors are present in particular in consumer lending, where their proportion of this funding grew from $26 \%$ in 2015 to $45 \%$ in 2016, and in business lending (growth from $24 \%$ to $29 \%$ ). There is a tendency for institutional investors to prefer the balancesheet model of invoice trading (Ziegler et al., 2018: 38).

While a considerable proportion of funding was directed to consumers (to finance consumption or real estate), funding businesses also experienced substantial growth, by $110 \%$ in 2016 . This funding however derived mostly from lending, in particular in France and the Netherlands, while in Germany the majority of funding to businesses originated from equity-based crowdfunding (Ziegler et al., 2018: 32-33). The average size of funding indicates clearly that equity-based crowdfunding is used by larger firms as fundraisers while start-ups or early stage business rely on crowdlending (Ziegler et al., 2018: 35).

The 2018 report gave information for the first time about onboarding and success rates for particular types of crowdfunding. The onboarding rate (acceptance of projects by the platform) is on average above $9 \%$ across all types of economic crowdfunding. However, while $25 \%$ of projects are accepted by consumer lending platforms, only $19 \%$ are successful in gathering funds. Conversely, onboarding on business lending platforms is stricter $(12 \%)$ and success rates much higher $(85 \%) .15 \%$ of projects are onboarded by equity-based platforms and $78 \%$ of campaigns are successful. It seems that more rigorous onboarding and project assessment gives more chance for success.

Both the 2016 and 2018 reports show the rising rate of automatic selection of projects by the platform instead of funders. In 2016 it was the case of $77 \%$ of consumer lending and $49 \%$ of business lending (Ziegler et al., 2018: 39). This gives more certainty to funders and fundraisers as to the expected interest rate and may speed up the campaign. However, it clearly charges the platforms with more responsibility for project assessment.

The new feature reported is the growing interest of platforms in internationalisation. In 2016, $77 \%$ of platforms had some funding from abroad and $44 \%$ of them directed funding to foreign projects (in 2015 it was, respectively, $54 \%$ and $24 \%$ ). However, the volume of those transactions was still limited except for consumer lending where $49 \%$ of inflows and $45 \%$ of outflows in volume were cross-border (Ziegler et al., 2018: 45-46). According to the information coming from platforms, diversified national regulation makes it difficult to provide cross-border crowdfunding services, which is reported to be more easily overcome in the case of consumer crowdlending (Ziegler et al., 2018: 46).

A 2018 report talks about the existence of national legislation dedicated to crowdfunding in 11 countries, and also about how substantial differences in this regulation make cross-border operations difficult. As to the substance of regulation, the opinions of platforms are divided between those who regard it as excessive and those who think it is lacking and needed ( $43 \%$ of equity-based platforms are of the first opinion, $5 \%$ of the second, $27 \%$ of consumer lending platforms are of the first opinion, $12 \%$ of the second) (Ziegler et al., 2018:51). However, the European Crowdfunding Network declares that, to facilitate cross-border operations of crowdfunding and to enable growth, pan-European harmonization of legislation is necessary (Ziegler et al., 2018: $54)$.

\section{Business models and practices of the crowdfunding platforms}

It should be kept in mind that crowdfunding platforms (lending and equity based) are in principle profitoriented agents, acting in the interest of participants but first and foremost in their own interest. This interest is making a profit as well as developing activities (for future profits). For this a good reputation is helpful. So their interests are coherent with the interests of some participants (fundraisers wishing to have broad access to finance, funders wishing to obtain more funding opportunities and relatively high rewards), but could also be contradictory (if, for example, a platform wishes to grow quickly and so accepts riskier projects). Another problem is the lack of clarity regarding the role of the platform itself - it can be purely a market place or an intermediary. In the role of intermediary, in particular under high levels of information asymmetry, the problem of the liability of the platform arises.

As to resolving problems linked to cross-group and within-group external effects, crowdfunding platforms may apply price and non-price strategies (Belleflamme et al., 2015 and 2016). The principal price strategy is to charge only one group of participants and not the other. Typically, fundraisers are charged and not funders. This cross-subsidization of the parties, by price preference, is aimed at attracting parties with insufficient number. Funders are in some way charged indirectly by foregone interest on the funds they contribute to before they 
are attributed to any project. Typically, transaction fees and not subscription fees are charged to successful fundraisers, so as to attract more fundraisers.

In the particular case of reward-based crowdfunding (which is not the focus of this paper), where nonfinancial rewards matter, being given for particular appreciation or request of early delivery of a product, platforms may apply price discrimination between sufficiently interested consumers and others. An analysis of the conditions and outcomes of such price strategy is provided in Belleflamme, Lambert, and Schwienbacher (2014).

Platforms may also apply non-price strategies, (Belleflamme, Omrani \& Peitz 2015; 2016; Cumming, Leboeuf \& Schwienbacher, 2015). They may propose two different funding mechanisms to fundraisers. One of them is called All-Or-Nothing (AON) and means that fundraisers have to declare a minimum threshold of financing. They would receive funds if this threshold is met, but nothing otherwise. The other possible mechanism is Keep-It-All (KIT), meaning that all funds collected are transferred to the fundraiser.

$\mathrm{AON}$ is perceived as potentially discouraging to fundraisers but providing additional valuable information to funders (in that fundraisers are aware how much they can collect). Within AON a platform may also apply measures encouraging funders to join projects close to meeting the threshold. This can smoothe the withingroup of fundraisers external effect (competition) and also the free-riding behaviour of funders.

As to the problem of asymmetry of information, the advantage of platforms is the economy of scope of data collection on beneficiaries and its analysis. However, the other side of this effect is strong information asymmetry between the platform (gathering important stocks of data) and its clients. This advantage is similar to that of banks, which have privileged access to information on their customers. However, contrary to banks, crowdfunding platforms are not party to financial transactions. They bear no risks, even though it is not clear whether they are intermediaries or not, and neither are platforms expected to be interested in using this information in all circumstances.

The platform is expected to provide some initial screening of projects. It is in the interest of the funders and of the platform itself (for reputational reasons). However, the interest of development may prevail resulting in the platform accepting weaker projects (Belleflamme, Omrani \& Peitz, 2015: 29). The other reason for loose screening is the cost of screening, quite high if the number of projects is high. As pointed out by Agrawal et al. (2013: 19) the quality of risk assessment can be lower than that of the banks, principally due to costs. The reason for the poorer assessment of the standing of projects can also be the reticence of fundraisers to disclose publicly information about their business (while information channeled to banks is by definition subject to banking secrecy), for fear of it being used by competitors (Gleasure, 2015: 223).

The level of interest from the crowd of funders, expressed by their willingness to fund, is the possibility of additional screening of projects. As demonstrated by Viotto Da Cruz (2016) even in cases of projects which did not collect the requested amount of funds in AoN, the owners of projects decided to continue their projects depending on the interest revealed by funders.

Platforms actually decline a large proportion of proposed projects (in the case of individual platforms it is 70 to $99 \%$ - Oxera, 2015: 6, the average for different types of crowdfunding is between $33 \%$ and $91 \%$ - Ziegler et al., 2018: 36). However, the evidence of losses of major UK platforms can indicate an insufficiency in screening (and is a source of creation of loss-covering funds by some platforms) (Milne \& Parboteeah, 2016: 11 - 13). Platforms themselves seem to be aware of their insufficient due diligence, because they express fears of rising default rates. They are also aware of the need for better scoring of projects submitted for selection and for matching decisions taken by the platform (Zhang et al., 2016: 21, 44).

In some crowdfunding business models the matching of parties is entirely carried out by the platform and the transfer of funds is operated between anonymous funders and fundraisers (Milne \& Parboteeah, 2016: 5; Zhang et al., 2016: 44). Thus, in this case the platform is not simply a marketplace, but an active agent, taking decisions on behalf of the parties. The decision is based on the automated optimization of funders' portfolios or taken manually by the representative of the platform.

Milne and Parboteeah (2016: 5) describe the automatic matching of funders and borrowers in crowdlending. One approach is an online auction conducted by the platform on the basis of the maximum interest rate borrowers are willing to pay and the minimum rate the lenders wish to receive. In the "reverse auction" the interest rate is gradually increased to achieve the full requested funding of the loan. If this rate is at or below the maximum rate declared by the borrower, the loan is funded, otherwise rejected. Another, also automatic, way of matching is to include lenders and borrowers in the risk categories with announced interest rates. In cases of imbalance between lenders and borrowers, the rates are adjusted.

Some recent sources indicate that the automation of decisions covers $77 \%$ of consumer crowdlending, $67 \%$ of traded invoices and $49 \%$ of business loans (Ziegler et al., 2018: 39). In such situations a platform can hardly be called an intermediary, because technically the funders are not active creditors or financial investors. Their role is rather like that of passive depositors in banks. However, contrary to a bank, the platform is not a party to any loan contracts and does not bear the financial risk of transactions. A separation takes place between 
the decision to take risks and the actual bearing of the risks. A platform is active in selecting borrowers and matching them with funders, but the risk is fully borne by the parties to the transaction, even though they do not know each other. The outcome for funders depends entirely on the rules and behavior of the platform.

Funding Circle is a platform enabling peer-to-peer lending to small businesses domiciled in UK and to borrowers looking for secured housing loans.

Borrowers are classified into six categories according to their risk rate provided by Experian (from A+ - the least risky to $\mathrm{E}$ - most risky). On this platform lenders pay a one-off fee according to the risk category and the maturity of the loans they wish to fund. The fee goes from $2 \%$ for short term loans in the A+ category (and for all housing loans) to $5 \%$ for longer term loans in higher risk categories. Funders have also to declare what proportion of their funding should go to individual loans.

The platform offers automated attribution of loans to funders, according to the risk category and maturity they have chosen. There is also a possibility for funders to individually choose loans they wish to finance, from those available and listed on the website of Funding Circle. Only institutional investors can finance whole loans. Ceasing to be a funder is subject to conditions (e. g. all funded loans repaid or sold).

Loans are activated when the funding reaches a ceiling pre-defined by the borrowers under conditions they have specified. At this moment a fee is charged to the borrower.

The platform defines itself as an intermediary, facilitating the matching of borrowers and funders, assessing borrowers' creditworthiness, preparing contracts and managing payments, along with enforcing. Platform may amend contracts, which are generated automatically between a funder and a borrower. The platform declares itself as not providing any advice.

Repayments are monthly and can be reinvested (unless specified). Business customers are allowed to repay loans early. Funders may sell entire loans or parts through intermediation of the platform.

Funding Circle, launched in 2010, made substantial losses in $2011-2014$, amounting to $4 \%$ of its stock of lending.

Source: Milne and Parboteeah (2016) p. 12-13 and www.fundingcircle.com accessed on 2/11/2017

This is not the only business model of crowdfunding platforms. The platform may just enable searching by funders and, in this situation, funders choose the investment opportunities themselves. They may rely on some elements of selection and/or of ranking of projects provided by the platform. In this model, transaction costs for funders are higher (due to search costs) and the problem of information asymmetry is still not solved. Funders can have projects presented to select, but still it is the platform which makes decisions on the range of information provided.

Crowdcube is a British investment crowdfunding platform. It was established by Darren Westlake and Luke Lang in 2011

In February 2013, Crowdcube received authorisation from the Financial Conduct Authority (FCA) to offer investors the opportunity to become direct legal shareholders in UK businesses

It reports on its website (on 14/01/2018) 630 successful campaigns, for $391 \mathrm{~m}$ GBP.

Crowdcube is involved in two types of business:

- funding equity of companies

- lending via selling bonds issued by companies.

Projects provide information which is checked and scored using UK based credit rating agencies (such as Experian) and additionally by the team. A general description of the project is published on the website and additionally investors can access information provided as restricted, published on the website.

Funding is carried out according to the All-or-Nothing principle and closes after 30 days. Fees are charged on projects, after successful funding. There are no fees for listing. After a successful campaign a fee of $7 \%$ of funds collected is charged. On top of this payment processing fees are charged ( $0.5 \%$ for UK, $1 \%$ for EU, $2.9 \%$ for the rest of the world).

Projects from outside UK may be accepted for funding under some conditions.

Investors choose projects themselves and indicate funds to forward to them. Investors are warned about any risks they bear.

Source: (Belleflamme, Omrani \& Peitz, 2015: 4); updated on 14/01/2018 according to www.crowdcube.com

One of the potential advantages of crowdfunding platforms is using the "wisdom of the crowd" in the sense of collectively identifying the most promising projects and preferred innovations ${ }^{8}$. However, taking into account the potential passivity of funders (at least on lending platforms) and the automatic attribution of portfolios to them, it seems that this advantage often doesn't materialise. Additionally, not all elements of support coming from social networks can be treated as reliable. For lending to households, it has been underlined that not all friends provide valuable information, but only those who actually invest in the given project (have "skin in the game") (Morse, 2015: 10). It also applies to small business projects, being similar to households in their involvement in social networks. 
There are different caveats to the operation of platforms. One of them is the strong tendency to concentration, due to the importance of the indirect network effect which depends on the volume of business organized by a platform (Martens, 2016: 12). This may encourage platforms to prioritize their growth of activity as opposed to the quality of accepted projects.

The differentiation of platforms makes their regulation difficult. In some ways they tend to self-regulate and at least set principles on their interactions with clients. Dealing with funds and funders is subordinated to the rules established by the platform, which should be made known to the funders. The performance of funded contracts is fully managed by the platform. Funders may have individual accounts from which funding is drawn and to which repayments accrue. However, in some business models all payments are outsourced to third parties (legally authorized payments entities).

The functioning of some types of platforms (in particular, where projects are automatically attributed to funders) is similar to that of a bank. It is an entity gathering funds from third parties (similar to deposits) and awarding them to individual fundraisers/borrowers. Neither depositors nor borrowers have a say in the rules of conduct of the banking business. However, contrary to a bank, a platform is not involved in any lending or investing contracts and does not bear any lender or investor risks, even though it actually plays an active role in selecting projects and matching funders with projects.

The difference is also that the activity of crowdfunding platforms is not specifically regulated at EU level, as opposed to the strict regulation both of banking activity and of capital markets. However, at EU level some pieces of legislation might apply to crowdfunding while in some countries dedicated national legislation exists. This legislation will be briefly summarized in the following.

\section{Risks for investors and platforms}

The fact that crowdfunding is a business where a platform intermediates between two different types of agents and where indirect network effects (interdependence between the interests of funders and fundraisers) exist, makes investor security impact on the reputation of platforms and on the performance of businesses as such. As was said above, fundraisers (SMEs in particular) benefit from sufficient numbers of funders and the platform should be interested in the feeling of security of the latter.

Crowdfunding however, is a business involving three types of parties, the interests and the conditions of activity of which are not the same. The type of risks most commonly put forward is that for the lender/investor. Some risks for platforms are the same as for funders, but also the platform can be a source of risk for the other two classes of participants.

The most significant risk for funders is that of non-performance of the projects funded. This could stem from the riskiness of the projects themselves (difficult to avoid in the case of start-ups) and from asymmetry of information between fundraisers and funders (or platform as their representative) $(, 2015)$. The risk of the failure of projects is identified as potential by research and appears in funder perception and can be detected by losses borne by some platforms ${ }^{9}$.

In all business models of crowdfunding funders are potentially exposed to a high risk of non-payment (European Commission, 2016: 16). On top of the risk of projects themselves together with information risk there are potential risks due to the platform (or a third party) failing to transfer money correctly, or even going bankrupt. Contrary to the depositors in banks, funders in crowdfunding are not covered by any public guarantee schemes. As said previously, some platforms have started to constitute internal risk safeguard funds to compensate for losses (Milne \& Parboteeah, 2016: 11 - 13).

If the funders select projects themselves, they are potentially subject to high information asymmetry with respect to investment projects, but also with respect to the platform, which channels data between fundraisers and funders and who might not be interested in facilitating full data transfer or ensuring its high quality, for example because of high costs, or the willingness to develop by attracting many, even more risky, fundraisers (Belleflamme, Omrani \& Peitz, 2015: 29).

In the business model where the funders do not decide where their funds go, they carry risks but cannot take measures to limit it ex-ante. In this business model a platform is potentially a substantial source of risk. It is not funders who accept the projects to be funded or select the ones to whom their funds will be channeled. The platform which selects and takes decisions is not liable for the risk to which it exposes funders. One way of limiting risk is the diversification of projects admitted for funding by the platform. On the funders side, the principal manner of reducing risk is by splitting their contribution between different projects, which, in this business model, is enabled by the rules of the platform ${ }^{10}$.

Information asymmetry can amplify exposure to the risk of the project itself in two ways. First, it can be a source of the negative selection of projects. With insufficient information ex-ante, bad projects (less well per- 
forming, with higher risks) are selected. This situation can be even more frequent than in the case of bank lending if platforms are not liable for risk, thus less interested in the careful selection of projects. There could be also conflicts of interest between the platform and projects (e. g. the personal involvement of managers of platforms in some projects) thereby increasing selection risk. Knowing about potential unfair selection could cause better projects to shy away ${ }^{11}$.

Asymmetry of information can also result in the uncontrolled disloyalty of fundraisers (moral hazard). This disloyal ex-post behavior (in particular if the platform, as non-liable, is not interested in monitoring the use of funds, or is unable to do it, due to the number of projects) can result in non-payment or delayed payments from fundraisers. As the situation of the platform in contractual relations is not clear and funders are involved in a big number of projects, the enforcement of contracts following project default can be very difficult (Milne \& Parboteeah, 2016: 22, 26). This would be particularly difficult if the platform itself defaults.

Funders however, can be impacted by other risks, for example due to the organization of crowdfunding. One of these is liquidity risk, because of the absence of a secondary market for crowdfunding securities and loans, or their difficult sale ${ }^{12}$. Some risks stem from the functioning of platforms, not of projects, for example the possibility of cyber-attack or insufficient initial screening of projects, or retention of payment by the platform or even its failure due to insufficient professional management. The bankruptcy of a big Swedish platform in Autumn 2015 showed the importance of these risks (Zhang et al., 2016: 47).

TrustBuddy AB operated as a peer-to-peer provider of loans. It offered peer-to-peer financing for small and medium-sized companies, and short or long-term consumer loans. The company operated under the Geldvoorelkaar, Prestiamoci, and TrustBuddy brand names primarily in Sweden, the Netherlands, Denmark, Finland, Spain, and Poland. The company conducted its operations through the company websites, trustbuddy.com and geldvoorelkaar.nl.

TrustBuddy AB was founded in 2009 and was based in Stockholm, Sweden. TrustBuddy was listed on the NASDAQ OMX First North stock exchange.

In August 2015 a new Board was installed and it discovered a 44 million SEK (around USD 5 million) discrepancy (amount missing from clients' accounts). The likely reason was that TrustBuddy was making loans to borrowers without the consent of lenders and not associating them with any particular fundraiser.

TrustBuddy was delisted from OMX and, upon the request of Swedish Financial Services Authority stopped all operations and in October 2015 filed for bankruptcy.

The behaviour of funders themselves can amplify the risks they bear. The funders and their motivations are differentiated. Considering low interest rates on deposits they may look for more rewarding placement of their money, namely on capital markets. The reason for choosing crowdfunding and not buying publicly traded securities is often emotional - interest in a particular project (when, in a given business model, details of the project are disclosed to them), or in this innovative manner of funding. According to research, for about $60 \%$ of funders the major motivation is emotional. They tend to make decisions quickly and "follow the herd" without rationally reflecting on investment decisions. However, these funders do not have the attitude of gamblers. Most of them (around $60 \%$ ) invest less than $10 \%$ of their savings in crowdfunding (Oxera, 2015: 4). Some investors are inexperienced and unaware not only of risks, but even of the rules of the functioning of the platform and of their rights. They are more concerned with security than rewards but, interestingly, they do not have high risk awareness. Investors consider themselves often as being financial experts, while in reality they are not. The research confirmed the greater wealth and awareness of funders on equity platforms (Oxera, 2015: 29-30).

A way of protecting funders against these risks could be by requiring them to have some investment experience. This is particularly relevant if funders are given a choice of projects. As risk is often due to the motivation of funders - quite often it is an emotional motivation - limiting the amount of funds invested can be also a suitable measure.

As was said previously, the interests of platforms are key to the design of rules of conduct. The awareness and preferences of potential funders can impact on the choice of platforms. As said, investors declare being more concerned with the security of their investment than with actual financial rewards (FSUG, 2015; Oxera, 2015: 55). Concerns about the reliability of platforms and about potential fraud are the principal reasons stated by the surveyed consumers for not investing in crowdfunding (Oxera, 2015: 5). Surveys and interviews also confirm that most platforms are interested in their reputation, understanding that it is a necessary condition of their functioning and development. Platforms themselves are increasingly concerned about the risk of increasing loan defaults or business failure rates, and also about collapse or malpractice by one of their peers, which could destroy the reputation of the profession (Zhang et al., 2016: 47, Ziegler et al., 2018: 48). In general, the managers of platforms reveal conservative attitudes and are making effort to enhance their risk management (FSUG, 2015; Oxera, 2015: 79). However, their desire to grow quickly and any financial constraints they meet can make them downplay risk (Oxera, 2015: 25). Moreover, due to high costs, the platform can be reticent to apply tools limiting risk (such as initial screening of projects and their further monitoring). 
An emerging feature of crowdfunding is the increasing involvement of institutional investors (investment funds, pension funds, banks) as funders. In a recent survey $44 \%$ of alternative finance providers indicated the participation of this kind of funders. A new feature is also emerging, that of institutional participation in platform shareholding, together with the growing prominence of bank-based FinTechs (Zhang et al., 2016: 4143). This changes the balance of power and, additionally, amplifies the risk of propagating the potential failure of platforms to more general, systemic risks, for the financial sector (Oxera, 2015: 13). As pointed out by Milne and Parboteeah (2016: 23) the involvement of institutional investors can bring about risks for the viability of platforms. These investors would be more willing to sell their assets (if this option was available) to readjust their portfolios, causing price volatility.

As for regulation, stakeholders have diverging views. According to surveys, funders usually ask for more external regulation, but platforms don't always, and they can prefer self-regulation instead (, 2015). As to the attitude towards existing regulation, the opinions of platforms are mixed, with in $201538 \%$ perceiving existing regulation of crowdfunding as sufficient, $28 \%$ as too strict and $10 \%$ as too relaxed (Zhang et al., 2016: 48). Similar diversity of opinions, for all crowdfunding business models, was also reported in 2016 (Ziegler et al., 2018: 51). However, as in the case of the introduction of national legislation in UK, platforms could also request regulation for reasons of reputation. Additionally, lack or insufficient harmonization of regulation is indicated in the recent public consultation on FinTechs as a deterrent to cross-border crowdfunding (, 2017).

\section{Crowdfunding from the perspective of fundraisers}

The principal reason why SMEs need crowdfunding is the reduced willingness of banks since the financial crisis to fund the real economy. This situation is particularly relevant for SMEs as banks are less keen to lend to them (Economic Analysis, 2015: 29). This is due to higher creditor risk stemming both from their projects (particularly the case for start-ups) and also from the greater difficulty of assessing risk, taking into account their smaller size (so more projects to be assessed for the same value of funding) and the lower capability of professional provision of information about the project by an SME. While in 2015 an easing of credit standards took place, according to an ECB quarterly bank lending survey, SMEs still encounter difficulties, like requesting personal guarantees or high non-interest costs (Zhang et al., 2016: 37). Thus, the principal interest of SMEs is access to funds by crowdfunding. In the context of the outcomes of the financial crisis of the previous decade, of the recession in some countries and of the small size of some of them, SMEs can also be interested in looking for cross-border funding. For these reasons crowdfunding was proposed in the framework of the Capital Markets Union (CMU Action Plan, 2015).

Crowdfunding is seen as an alternative to bank funding in the case of refusal by a bank ${ }^{13}$. Thus, there is by definition a negative selection of projects applying for this type of funding. As said previously, platforms reject a large proportion of projects proposed for funding. Platforms perform some risk screening, which can be however more superficial ${ }^{14}$ than that of banks. One reason for this is the cost of assessment for platforms, another - less easy access to external information on projects and probably the lower quality of information received from projects themselves. Finally, the number of small projects to be assessed amplifies costs (Agrawal, Catalini \& Goldfarb, 2013: 6, 19).

One of the risks identified for fundraisers in the Opinion of the European Banking Authority is uncertainty as to how project risk assessment is carried out within crowdfunding (EBA, 2015). EBA suggests that there may be no rules either about the information that should be provided by the borrower, or how the assessment is carried out. In the case of equity crowdfunding there is in principle no obligation to issue a prospectus by the project because of its low size, so less detailed information is provided (Mapping, 2015). A conflict of interest can also arise between the management of the platform and the borrower. This exacerbates the risk of negative selection (where projects of lower quality are accepted, and projects of higher quality rejected, due to a conflict of interest or the insufficient quality of assessment). SMEs can be rejected while providing good projects, but which are for example insufficiently or unprofessionally described. There can be also cases of acceptance of unfeasible projects, which should not be continued, to avoid detriment to the fundraisers themselves. Further, the risk of a biased choice of projects is even higher if funders make decisions autonomously because these decisions are often emotional ("excitement by the project").

As to access to funds, crowdfunding platforms give substantial advantage by the possibility of risk sharing. If the business model of the platform requires splitting funds between different projects, lenders/investors are substantially less exposed to the risk of individual projects they fund within their portfolios. This is an advantage for fundraisers with riskier projects (like start-ups) which may be given the possibility of having them accepted for funding. The condition of using this opportunity by more risky projects without exposing funders to excessive risk is however a professional design of portfolios constituted for lenders/investors. 
The success of fundraisers has different aspects. One of them is receiving funds. Here, obviously the quality of the project is essential, but also the quality of the project description (for example, in the case of business projects, providing a video) and the network supporting the fundraiser. But success in receiving funds does not guarantee success in delivering the project. As reported by Mollnick (2014: 11-13), the majority of successfully funded projects on Kickstarter were delayed, some of them substantially. Less than $5 \%$ of projects failed totally.

If a platform carries out loose monitoring of the use of funds (or does not ensure it at all), the situation can be in fact detrimental for the fundraisers, even though they don't recognize it. Starting from small delays in repayments or deviations in the implementation of projects they can fall into a spiral of over-indebtedness or non-completion of projects. This is the risk both for households as fundraisers, and SMEs, in particular the smallest ${ }^{15}$. As underlined by Paschen (2017), start-ups and small SMEs, at different stages of development, are served by different kinds of crowdfunding: donation at pre-startup stage, lending for startups and equity crowdfunding at growth stage. The awareness of small business increases in consecutive stages of development.

Other risks for fundraisers are related to liquidity. As the payments are operated by the platform or a third party, the liquidity risk for fundraisers is due to defaults on the side of funders (delay in provision of funding) or of the platform itself. In the case of delays in transferring repayments from fundraisers to funders by the platform or some third party operating payments, there is a risk to reputation or even the possibility of litigation against a fundraiser. The major risk is discontinuation of the activity of a platform itself.

This last risk is related to the opacity of contractual relations between the parties. Fundraisers and funders can be unaware of their reciprocal rights and obligations as being different from the obligations and rights of the platform. For example, there is insecurity as to monitoring projects (who should do it - the funders, who are many, or the platform?), implying moral hazard linked to the unsuitable use of funds. If all payments are operated by the platform, fundraisers can be unaware of their payment commitments. They can be unaware (and appropriate arrangements can be missing) of their responsibility in the case of the default of the platform itself $^{16}$. This can lead to long lasting disputes and finally to losses for all parties, fundraisers included.

Furthermore, cross-border activity of crowdfunding platforms serving business is still small, and this is due to the fragmented regulatory frameworks (Expanding, 2018: 46). Thus, the need of SMEs to seek funds crossborder is not met.

In conclusion, while crowdfunding addresses some fundraiser needs (more access to funds), it does not address all of them (for example cross-border financing) and moreover, exposes borrowers to substantial risks. It is important to note, that the smallest SMEs being fundraisers seem to deserve protection to avoid engaging in unfeasible projects, like natural persons being borrowers. This is different from the usual principles of protection, where it is possible to distinguish between the stronger and the weaker party, and where the business is always considered stronger and not deserving of protection.

\section{Regulation of crowdfunding}

\subsection{Problems to be solved by regulation}

The crowdfunding business is developing. Platforms are concentrating, trying to make the best use of external network effects. Due to their increasing size, they are more and more dominant over the participants on both sides. Moreover, some elements of new business models driven by economy of transaction costs (participants being totally replaced in their decisions by platforms) amplifies the previously mentioned asymmetry of power between the platform and the other two types of agents involved. This creates a particular contractual situation and makes difficult a purely market driven adjustment of internal rules in the interests of all parties involved. However, the involvement of big institutional investors (investment funds and pension funds) on the side of funders changes the balance of power.

The interests of the three parties involved in crowdfunding (platform, funders and fundraisers) are significantly different.

Funders are interested in getting rewards from platforms that are higher than from banks (Milne \& Parboteeah, 2016: 4). However, they bear substantial risk (of the projects themselves, of asymmetric information with respect to fundraisers and to platform) and there have been requests from some funders to enhance their security. They can suffer losses due to errors in the transfer of money between fundraisers and themselves, or due to the bankruptcy of the platform. They can also be sources of risk for themselves due to insufficient knowledge or emotional choices. Pressure from potential funders emerges, who do not trust platforms and do not want to engage in crowdfunding. However, as not only fundraisers, but also the platform can be a source of risk (through too relaxed rules of project selection, by the unclear manner of attribution of projects to funders) there is also a clear conflict of interests between platform and funders. 
Fundraisers are interested in access to funds, potentially also cross-border. A distinction should be made between bigger fundraisers (typical using equity crowdfunding) and smaller fundraisers using lending platforms (small SMEs and households) (Paschen, 2017: 182 - 183). The latter are probably less aware of risks they bear, which can stem from their own project (and even its unexpected success in gathering funds), but also from the rules of the platform (negative selection of projects - good projects not selected, acceptance of unfeasible projects, tolerance of inappropriate use of funds, unclear contractual obligations). Some fundraisers are also aware of the risks of sharing information about their projects - as underlined by Gleasure (2015). A clear conflict of interest exists between funders and fundraisers, the projects and behavior of the latter being a source of risk for the former. The conflict of interest between fundraisers and platform is less apparent, but real.

Platforms are between these two requirements - that of acquiring a good reputation and the other, of growing faster than its peers (and gaining high profits). ${ }^{17}$ These two objectives are contradictory. The risk for a platform is of losing reputation, not of money engaged, as it is not a party to the contracts. For this reason, even if platforms avail themselves of tools to better select projects, the pressure to grow and to reduce costs can limit their willingness to use them.

The situation of a platform is complicated by the fact that in some way it represents both funders and fundraisers, who both have contradictory interests. The type of involvement of the platform (as a passive, not active party to transactions) lowers its sensitivity to risks borne by other participants. Due to this ambivalent situation it is subject to information asymmetry (from fundraisers), but is also potentially a source of asymmetry to funders. It is important to note that according to internal rules the platform gains on the amount and value of funded projects and on the number of participating funders. Its economic interests stop at the moment of successful funding. The platform neither gains nor loses on the performance of the project.

Thus, the institutional situation is complicated. Conflict of interests exists not only between funders and fundraisers, but also between both of them and the platform, which is not a perfect representative either of the former, or the latter. The difference of power (with platform dominating the other two) makes control of the participants over the platform and negotiations on terms of cooperation particularly difficult, if not unfeasible.

The most important concern of platform participants, even more important in the framework of new business models, is the liability of platforms for decisions they make, impacting on rewards and losses for funders and fundraisers. Introducing some form of liability of the platform would better align its incentives with the party more exposed to risk, namely the funders.

The liability may be either economic or legal. If the former, a spontaneous alignment of interests could take the form of sharing both rewards and losses of projects between the platform and the funders. However, this cannot be solved by platforms themselves, as it is clearly not in their interest. There is thus an objective need for external regulation, imposed top-down, with some legal liability of the platform. ${ }^{18}$

Control of the functioning of platforms by reputation and competition may be another, although much weaker, means of aligning their interests with those of participants. Awareness of unfair practices of peer platforms makes the others request regulation to enhance their reputation. Platforms are to some degree interested in the introduction of pan-European regulation of their activity because they wish to operate in all European countries based on being registered in one of them ${ }^{19}$. Differences in national legislations are barriers for their cross-border operations.

As crowdfunding platforms grow and involve institutional investors, there is a more equal balance of power. Other interested parties are entering the game. Banks perceive crowdfunding as a serious competitor to their activities, with a competitive advantage due to the lack of physical locations for their activities and not being subject to regulation (Oxera, 2015: 12), and ask for a level playing field. The need for regulation (and for its enforcement) to ensure the stability of the financial sector is spelled out by the representatives of supervisors and industry ${ }^{20}$.

The history of crowdfunding is short, and relevant legislation has not been fully developed yet. Additionally, on the legislators' side there has been an attitude of "wait and see" (European Commission, 2016: 6). However, in some countries specialized legislation has been developed. The concerns the most frequently underlined with respect to crowdfunding were asymmetry of information (between funders and fundraisers, and also between the participants and the platform) and also the insufficient experience of funders. These were the elements that the self-regulation of associations of platforms and legislation of European countries tried to remedy (Viotto, 2015: 45).

\subsection{Existing national legislation}

According to Mapping (2015: 42 - 74) three EU Member States have introduced early more comprehensive national legislation regulating the activity of crowdfunding platforms ${ }^{21}$.

The earliest legislation (June 2013) was introduced in Italy. It enabled the activity of equity crowdfunding platforms subject to registration with the regulator of the stock exchange (CONSOB). Platforms are obliged 
to comply with rules of conduct and rules concerning offers made via the platform. The legislation enabled the funding of innovative start-ups (and was later widened). Access to platforms was limited to sufficiently knowledgeable investors and platforms were obliged to provide the investors with detailed information about projects funded. The funders of smaller contributions (below €500) were less protected, while the bank or investment company with which the platform was obliged to cooperate (among others to operate transfers of clients' money) had some compliance obligations to funders providing higher amounts (Mapping, 2015: 45). As for lending platforms, the Bank of Italy's approval and licensing as a financial institution or payment intermediary was required. This legislation, introduced at a very early stage of crowdfunding, when the number of platforms was very low (8) was perceived as restrictive and did not stimulate its development.

The United Kingdom introduced regulation of crowdfunding platforms in April 2014. Both equity and lending platforms had to be authorized by the Financial Conduct Authority and obliged to declare sound client money management rules, disclosure requirements, prudential regulations and programmes for platform failure. Participation in equity platforms was restricted to experienced investors or those who declared that they would not invest more than $10 \%$ of their assets. The regulation was prepared in consultation with the industry and was supported by platforms themselves, which wished to gain better reputations. Through crowdfunding the government intended to give an alternative to SMEs who had been turned down by banks. The launch of new crowdfunding platforms slowed down after the introduction of the regulation, but overall continued to grow.

France introduced regulation of platforms in May 2014. Prior to that, platforms operated as credit institutions or investment services providers. New regulations, preceded by public consultation, gave the platforms the opportunity to operate either as equity, or lending platforms. An obligation to register as a payment services provider was introduced for platforms operating money transfers. Besides obligations of conduct and management competences, an obligation to check the financial understanding of investors and operate their "staged access" was introduced. The issuance of securities offered by the same issuer was restricted to $€ 1 \mathrm{~m}$ over 12 months. If prospectuses were not required, issuers had to provide investors with simple information about the project. The equity platforms had to ensure that investment was relevant to investor experience, situation and preferences. For lending platforms only individuals could be lenders of interest-bearing loans. Loans funded by platforms were restricted in size to $€ 1 \mathrm{~m}$. As to lenders, their contributions were restricted to $€ 4,000$ per project and lender for interest-free loans and to $€ 1,000$ for interest-bearing loans.

While there are many common elements in national crowdfunding legislation (protection of funders, imposition of requirements on platforms to ensure more security) the scope and details of solutions diverge.

\subsection{Possible use of existing EU legislation}

One of the needs of crowdfunding platforms is to operate cross-border. This can be necessary for speeding up their growth. However, cross-border passporting should be accompanied by some harmonization of the standards for the functioning of crowdfunding to overcome barriers stemming from differentiated national legislation. Therefore, EU legislation is needed.

As for equity-based crowdfunding, potentially it could be regulated by the Prospectus Directive ${ }^{22}$ and Markets in Financial Instruments Directive (MiFID) ${ }^{23}$. The Prospectus Directive obliges an issuer of securities (also equity fundraisers) to publish a prospectus before issuing. This would enhance the information provided to investors. However, the obligation to prepare prospectuses is limited to the issuance of transferable securities (in a broad sense, also those potentially sold), and to offers exceeding $€ 5 \mathrm{~m}$. The majority of projects financed by crowdfunding would probably not come within this requirement.

As to MiFID, it is applicable to investment intermediaries. If a platform intermediates in sales of transferable securities, it would fall within the requirements of MiFID which are substantial. First, the platform would need to be registered and authorized as an investment firm and have sufficient capital. It should, in principle, carry out a suitability assessment of securities sold to customers (being both natural and legal persons) and provide them with suitable advice.

The problem is what the role of the crowdfunding platform in the contacts between investors and projects is (ESMA, 2014). MIFID defines the type of financial products and of financial services of investment intermediaries within its scope. If the platform simply communicates to projects the "expression of interest" of potential investors, it would not classify it as an investment firm ${ }^{24}$. If the platform executes orders on behalf of investors however, it would clearly fall under MiFID.

ESMA (2014) clearly underlines that equity-based crowdfunding platforms which could be within the scope of MiFID, often escape its requirements, as being too constraining. However, their adoption would enhance the security of investors ${ }^{25}$ and of platforms (e. g. due to capital requirements). An additional advantage for the platform is that authorization under MiFID automatically gives a passport to operate across the EU, which is very favourable as it enables platforms to grow by developing cross-border ${ }^{26}$. 
Even though MiFID does not apply to nontransferable securities, and products sold in crowdfunding are usually of this type ${ }^{27}$, Member States can extend some requirements of this directive to platforms, for example requiring their authorization, application of rules of information disclosure and of avoidance of conflict of interest. MIFID-like requirements protecting funders already exist in different national legislations for crowdfunding (including crowdlending).

Crowdfunding platforms can handle money transfers between parties to transactions (funders and fundraisers). In this case they should be registered as payment institutions and respect the Payment Services Directive $(\mathrm{PSD})^{28}$. The obligation imposed by this directive to separate the funds of clients and of the platform is important for the financial security of the parties. However, it is not the only business model. Transfer of funds can be (and often is) outsourced to a professional organization registered as a provider of payment services.

Some aspects of the functioning of crowdlending platforms fall under existing European legislation. This would be the case of transactions between legal or natural persons (if they act in their professional capacity) as funders and natural persons as borrowers. Based on the Consumer Credit Directive - CCD ${ }^{29}$ and Mortgage Credits Directive - $\mathrm{MCD}^{30}$ some borrowers (only natural persons) would have the right to advertisements (e. g. on the website of the platform) in a standardized form. They should also obtain pre-contractual information before the signature of the contract, and a contract fulfilling the legal requirements. They would have the right to withdraw from a loan contract within 14 days and to repayment of the loan earlier than planned.

However, crowdfunding is generally intended to be peer-to-peer, without excluding either natural or legal persons on any side. For this reason, consumer protection legislation (for example CCD or MCD or else Distance Marketing of Financial Services Directive ${ }^{31}$ - DMFSD) addressing only business to consumer selling, does not apply to all transactions within these platforms.

Enforcement of those rights would thus depend on the assessment of those who are funders acting as lenders. In cases where they are natural persons or are totally passive (not choosing particular borrowers), or if their individual contribution is very small (below the threshold of $€ 200^{32}$ ) it would be difficult to apply the rules to them as creditors, and to the platform as an intermediary. Otherwise, the platform, as an active agent of the transaction, could be treated as a creditor. It would be also difficult nonetheless to do this, the platform clearly not being a party to the contract, while performing some creditor duties (such as the assessment of creditworthiness). Thus, there is a problem of enforcing the protection of borrowers offered by the European legislation on loan-based crowdfunding.

\subsection{Need for further regulation of crowdfunding}

Some suggestions as to potential regulatory measures for lending-based crowdfunding were listed by the European Banking Authority (EBA, 2015). The major concern was the status and operation of platforms ${ }^{33}$.

- Platforms should duly disclose information about borrowers/projects. They should carry out sufficient creditworthiness assessment or inform lenders that it has not been carried out. They should require information from borrowers sufficient for this assessment and, in the case of negative outcome of assessment, refuse the project funding.

- The rights and obligations of parties should be clearly spelt out and standard contracts should be provided on websites. It has been suggested that the categorization of lenders according to their knowledge profile should be carried out.

- Platforms should be registered as financial providers. The professional capacities of managers should be checked. Conflict of interests (like involvement of platform staff in borrowers' businesses) should be prohibited or clearly declared to the potential parties.

- Platforms should take and disclose arrangements in case of their failure or discontinuation.

- Platforms carrying out payment services should separate their own money from lender's and borrower's money. In the case of transfers, Payment Services Directive applies, and platforms should be registered.

In principle, these requirements, which focus on the protection of funders and on the functioning of the platform, are applicable to all types of platforms (both equity and lending-based). They also show the difference between crowdlending and classical lending by professional creditors (such as banks). In the latter case there is no need to protect a funder (bank), while in the former funders need protection.

As to the points listed by EBA, platforms can spontaneously improve information provided to funders, better inform fundraisers about what information to provide and better select projects, and also publish standard contracts on websites. They can classify funders according to their knowledge and appetite for risk. These 
changes do not impose substantial costs and improve reputation. Some similar requirements already apply due to dedicated national legislation. Secondary markets for products sold by the platform seem to develop and if standardization progresses they will further develop and limit liquidity risks for funders (Milne \& Parboteeah, 2016: 23)

Additionally, some elements of existing European legislation described in the previous section can be extended to platforms, namely for equity-based crowdfunding (MiFID, PSD). Rules like MiFID (obligation to get authorization, to avoid conflict of interests, to provide fair information to clients) can also be applied to protect funders in crowdlending. This would partly address the P2P nature of crowdlending (with respect to funders of different legal standing).

However, substantially better alignment of the interests of the platform and the participants would be difficult to achieve without specific legislation dedicated to crowdfunding. It would need to make platforms liable for screening of projects and for decisions taken in place of funders, or financially interested in high rewards and low losses generated ex post by the projects (having "skin in the game"). This would however be opposed by the platforms like the obligation to reject unsuitable projects proposed by EBA. However, the MiFID principle (Article 25) of making a platform obliged to assess the suitability and appropriateness of products advised or sold to funders can be applied as a softer version of liability.

The most difficult gap to fill in emerges with respect to the protection of fundraisers. This is not spelled out in the opinion of EBA. On the contrary, EBA wishes to protect funders by disclosing information about the borrowers. MiFID does not contain specific rules for protecting fundraisers. This is because providers of securities as fundraisers are considered sufficiently knowledgeable and not requiring protection. As in practice bigger and more experienced projects seek funding equity by crowdfunding, this assumption seems relevant and justified in this case ${ }^{34}$.

The situation is different in crowdlending, both to households and to SMEs. Fundraisers, if natural persons, are already recognized in EU legislation as having the right to protection according to CCD and MCD. As said previously, those rights cannot be insured by funders in crowdlending, due to their dispersion and the difficulty of verifying whether all funders are professional creditors or not. It seems that to ensure these rights a clear role for the platform (at least as credit intermediary for a community of lenders) should be introduced. Similar protection could be awarded to SMEs when funded by crowdlending, due to the fact indicated above that they are small, often start-ups and the financial knowledge of the smallest SMEs does not differ from that of households. Some platforms are of mixed type (lending to households and to SMEs) and the type of borrower can change during the duration of the loan (a household can start a small business).

\section{Conclusion}

In the transactions organized by crowdfunding, three types of participants can be seen: funders, fundraisers, and platforms. Their interests diverge. A clear conflict of interests emerges between funders and fundraisers. This situation is similar to that in banking, between lenders and borrowers, based on asymmetry of information. However, the situation of funders exposes them to more risks than banks, who are professional lenders, able to better assess project risks and risk stemming from asymmetry of information. Funders moreover, may be a source of risk for themselves, due to the emotional decisions they make.

The relationship between the platform and both types of participants is ambivalent. Platform is interested in profit and growth. For this reason, its interests are more aligned with those of fundraisers, who want access to funds. Conflict emerges when a platform assesses a project as unsuitable and chooses to reject it. This happens if a platform perceives risk to its reputation in a given situation as higher than reward in terms of growth. However, good reputation is needed to attract participants. The failure of a platform (as in the case of TrustBuddy a couple of year ago) can be detrimental to all these businesses.

As to the coherence of interests of platform and funders, this is more complicated. In theory, a platform should represent the interests of funders, among others by the careful screening of projects. However, the platform is not involved in contracts between funders and fundraisers and its role and liability for decisions it takes, is unclear. It is expected to carry out screening of projects, but EBA opinion and some sources (Belleflamme, Omrani \& Peitz, 2015: 29, Milne \& Parboteeah, 2016: 11-13) suggest that this assessment might be insufficient. In recent developments, in particular of crowdlending, a platform replaces funders in their decisions, without bearing liability.

Thus, solutions better protecting the funders and the fundraisers from different risks are needed. As there is a major asymmetry of power (a platform dominating the other two types of parties), this cannot be solved, according to institutional economics, by the spontaneous adjustment of the internal rules of platforms, for example sharing rewards and losses of funded projects. Therefore, there is a need for the regulation of crowd- 
funding. Some elements of this need have been indicated in the opinion of EBA (2015). Up to now, dedicated regulation of crowdfunding has been introduced in eleven countries of the European Union. However, growing platforms need to extend their activity cross-border. In this situation, existing national legislation does not help, due to the lack of harmonization.

Some pieces of European legislation are at least partly applicable to crowdfunding. This is the case of MiFID with its requirements for the protection of investors and of the prudent functioning of the platform as an investment intermediary (including capital requirements), or of PSD. Platforms however tend to circumvent this legislation. As to MiFID it seems surprising, because it is a way of getting a passport to operate cross-border. One reason for this could be that MiFID requirements are perceived as too restrictive, another - that the not fully harmonized application of MiFID by countries does not actually allow for cross-border operations.

The need to meet the interests of platforms and partly to protect investors was addressed by the recently (on 8/03/2018) published proposal for the Regulation on European Crowdfunding Service Providers for Business ${ }^{35}$. Its principal objective is to enable platforms authorised by ESMA to operate cross-border by offering exclusively business loans and participation in equity in the form of transferable securities. This regime would exist side by side with national crowdfunding regimes and cross-border platforms authorised by ESMA would be excluded from the supervision of national authorities. Platforms are not under any capital requirements. They are requested to strengthen rules on conflict of interest, which protect both funders and fundraisers (and is the one of the rare examples $s$ of fundraiser protection, along with harmonization of information on the project to be provided to the platform). Funders are in principle expected to make their choices independently (or, if it is platform who makes choices, to be informed about the methodology according to which the choice was made). Platform is not liable for the outcomes for funders and there is no direct obligation of screening projects to be funded. The protection of funders as decision makers is somehow strengthened (by initial testing of their knowledge by the platform and warning if the services were found to be inappropriate to them, and by provision of standardised Key Investment Information sheets on each offer), without essentially enhancing the liability of the platform.

This legislation could better protect investors. It does not fill the gap existing in respect to the protection of fundraisers, in particular of borrowers on lending platforms. In principle, the protection of household borrowers (excluded from the scope of the Regulation described above) is ensured by dedicated consumer-oriented legislation (CCD and MCD), but in practice its implementation is disabled by the peer-to-peer nature of transactions on platforms and needs specific legislation.

\section{Acknowledgment}

A previous reduced version of this article was published in Polish by the journal Gospodarka Narodowa of the Warsaw School of Economics (ISSN 2300-5238) available at: http://gospodarkanarodowa.sgh.waw.pl/p/gospodarka_narodowa_2018_01_03.pdf.

\section{Notes}

1 Recently expanding use of Big Data and automated scoring can limit costs of screening.

2 Securitization, allowing selling out risk, modified this attitude (Shin, 2009). Banks may be thus less cautious about project risks.

3 As reported by Camerer and Loewenstein (2003) people can be subject to different biases leading them into different behaviours. In practice it is impossible to produce a general model of actual human behaviour.

4 This is a classical assumption in game theory often applied in studying spontaneous change in institutions.

5 "To the degree that there are large payoffs to influencing the rules and their enforcement, it will pay to create intermediary organizations (trade associations, lobbying groups, political action committees) between economic organizations and political bodies to realize the potential gains of political change" (North, 1990: 87)

6 Ramsay (2015) nicely illustrates this game in the process of negotiations of the European Consumer Credit Directive.

7 Similarly, the diverging incentives and disincentives of different participants in crowdfunding were studied by Agrawal et al. (2013: 10 20).

8 This is the most evident in cases of the direct funding of creators in art or innovators but may be relevant for lending and equity also (Agrawal, Catalini \& Goldfarb, 2013: 33). This is also underlined by Paschen (2017: 180-182).

9 As by some UK crowdlending platforms, as reported by Milne and Parboteeah (2016): 10-13.

10 In FirstCircle platform a $£ 100$ contribution may be spread over 100 borrowers (Milne \& Parboteeah, 2016: 5).

11 Pointed out in a well-known article by Akerlof (1970).

12 Milne and Parboteeah (2016: 21) confirm the existence of secondary markets in crowdlending, but within the same platform.

13 It was even spelled out in UK regulation of crowdfunding (Mapping, 2015: 54).

14 For example, based on Big Data and comparison of applicants with statistical samples.

$151 / 3$ of newly created European SMEs do not survive the first 2 years of operation (, 2016: ch.4). Often the entrepreneur-beginners are unable to take steps quickly enough to avoid bankruptcy (Ecorys:34). 
16 After the collapse of TrustBuddy some borrowers thought they were no longer bound by repayment obligations. Most probably it was because the contract between both parties was not clear enough to engage borrowers to pay back and allow lenders to enforce claims. (http://www.alfti.com/article/1505 TrustBuddy saga rolls on, accessed on 29 November 2017).

17 This internal conflict of interests can impact, for example, on the willingness of the platform to fairly disclose all information about fundraisers (Belleflamme, Omrani \& Peitz, 2015: 29).

18 Some re-intermediation of crowdfunding and incentivization of platforms to better perform risk assessment when "having skin in the game" is claimed by some researchers (e. g. Morse, 2015: 21-23).

19 It was spelled out in the consultation on FinTechs recently carried out $(, 2017)$ and by the European Crowdfunding Network, as reported in Ziegler et al. (2018) (54).

20 Issuing opinions by ESMA and EBA a couple of years ago is already proof of this (ESMA (2014) and EBA (2015)).

21 Up to now (November 2017) eight more countries have introduced some regulation of crowdfunding.

22 Directive 2003/71/EC OJ L 345 of 31.12.2003.

23 Directive 2004/39/EC OJ L 145 of 30.04.2004.

$24 \mathrm{MiFID}$ contains in art. 3 the possibility for Member States of an optional exclusion of entities carrying out only reception and transmission of orders and providing advice in respect to this, on the condition that those firms are regulated at national level. However, it is difficult to determine whether the services of crowdfunding platforms consist in transmission of orders or in placing of securities without firm commitment (which, according to ESMA, does not allow for exclusion from MIFID).

25 Assessment of the suitability of products sold by investment intermediaries imposes some form of liability for outcomes for investors.

26 However, this advantage may not materialise if internal national regulation (including implementation of MiFID) is not harmonized.

27 As said previously, the sale of products of crowdfunding is already possible within some platforms, and standardization of products can enable broader transfers.

28 Directive 2007/64/EC OJ L 319 z 5.12.2007.

29 Directive 2008/48/EC OJ L133 of 22.05.2008

30 Directive 2014/17/EU OJ L60 of 28.02.2014.

31 Directive 2002/65/EC OJ L271 of 9.10.2002.

32 Consumer Credit Directive does not apply to loans below €200. However, for crowdfunding the question would be what a loan is individual funding by each funder, or the total funding received by a fundraiser.

33 The elements of this opinion indicate clearly the weaknesses of the operation of platforms.

34 It is confirmed by Paschen (2017:183) that equity crowdfunding is suitable rather for bigger SMEs.

$35 \operatorname{COM}(2018) 113$ final available at: https:/ /ec.europa.eu/info/publications/180308-proposal-crowdfunding_en

Note: The information and views set out in this article are those of the author and do not necessarily reflect the official opinion of the European Commission.

\section{References}

Agrawal, A. K., Catalini, C., \& Goldfarb, A. (2013) Some simple economics of crowdfunding, Working Paper No 19133, National Bureau of Economic Research.

Akerlof, G. A. (1970). The market for "Lemons": Quality uncertainty and the market mechanism. The Quarterly Journal of Economics, 84(3), 488500.

Akiba, M., \& Lissowska, M. (2006). The behavior of credit granting and institutionalization of commercial banks in Poland. Japanese Journal of Comparative Economics, 43(2), 43-50.

Annual Report on European SMEs 2015/2016 (2016) European Commission, Luxembourg.

Baltowski, M., \& Kozarzewski, P. (2016). Formal and real ownership structure of the Polish economy: State-owned versus state-controlled enterprises. Post-Communist Economies, 28(3), 405-419.

Belleflamme, P., Lambert, T., \& Schwienbacher, A. (2014). Crowdfunding: Tapping the right crowd. Journal of Business Venturing, 29(5), 585609.

Belleflamme, P., Omrani, N., \& Peitz, M. (2015) The economics of crowdfunding platforms, CORE Discussion Paper No 15, Louvain-la-Neuve.

Belleflamme, P., Omrani, N., \& Peitz, M. (2016) Understanding the strategies of crowdfunding platforms, CESifo DICE Report No 2.

Bhattacharya, S., \& Thakor, A. V. (1993). Contemporary banking theory. Journal of Financial Intermediation, 3,2-50.

Camerer, C. F., \& Loewenstein, G. (2003). Behavioural economics: Past, present and future. In C. F. Camerer, G. Loewenstein, \& M. Rabin (Eds.), Advances of behavioural economics. Princeton: Princeton Press.

CMU Action Plan (2015), European commission COM(2015) 468 final, Brussels.

Cumming, D. J., Leboeuf, G., \& Schwienbacher, A. (2015) Crowdfunding models: Keep-It-All vs. All-Or-Nothing. Available at SSRN: https://ssrn.com/abstract=2447567 or http://dx.doi.org/10.2139/ssrn.2447567

Deakin, S., Gindis, D., Hodgson, G. M., Kajnan, H., \& PIstor, K. (2017). Legal institutionalism: Capitalism and the constitutive role of law. Journal of Comparative Economics, 45(1), 188-200.

Diamond, D. W. (1984). Financial intermediation and delegated monitoring. The Review of Economic Studies, 51(3), 393-414.

EBA (2015) Opinion of the European banking authority on lending-based crowdfunding, EBA, 26 February 2015, https://www.eba.europa.eu/documents/10180/983359/EBA-Op-2015-03+(EBA+Opinion+on+lending+based+Crowdfunding).pdf

Economic Analysis (2015), Commission staff working document accompanying the document communication from the commission to the European parliament, the council, the European economic and social committee and the committee of the regions action plan on building a capital markets union, SWD(2015) 183 final; http://ec.europa.eu/finance/capital-markets-union/docs/building-cmu-economicanalysis_en.pdf

Ecorys. (2014). Bankruptcy and second chance for honest bankrupt entrepreneurs. Brussels: EU Publications. 
Entrenching Innovation. The 4th UK alternative finance industry report (2017) Cambridge Centre for Alternative Finance, University of Cambridge Judge Business School.

ESMA (2014) Advice. Investment-based crowdfunding, European Securities and Markets Authority 18 December 2014; https://www.esma.europa.eu/sites/default/files/library/2015/11/2014-1560_advice_on_investment-based_crowdfunding.pdf

European Commission (2016) Crowdfunding in the EU capital markets union, European Commission 2016, SWD(2016) 154 final; http://ec.europa.eu/finance/general-policy/docs/crowdfunding/160428-crowdfunding-study_en.pdf

European Commission (2017) Summary of contributions to the 'Public Consultation on FinTech: A more competitive and innovative European financial sector', Brussels; https://ec.europa.eu/info/sites/info/files/2017-fintech-summary-of-responses_en.pdf

Fiori, S. (2002). Alternative visions of change in douglass north's new institutionalism. Journal of Economic Issues, XXXVI(4), 1025-1043.

FSUG (2015) Financial services users group position paper on the study of "Crowdfunding from an Investor perspective", Brussels.

Cleasure, R. (2015). Resistance to crowdfunding among entrepreneurs: An impression management perspective. Journal of Strategic Information Systems, 24, 219-233.

Hall, P., \& Taylor, C. R. (1996). Political science and the three new institutionalisms. Political Studies, XLIV. 44, 936-957.

Henisz, W. J., \& Zelner, B. A. (2003) Legitimacy, interest group pressures and institutional change: The case of foreign investors and host country governments, William Davidson Institute Working Paper No. 589. Available at SSRN: https://ssrn.com/abstract=577761 or http://dx.doi.org/10.2139/ssrn.577761

Henisz, W. J., \& Zelner, B. A. (2006). Interest groups, veto points, and electricity infrastructure deployment. International Organization, 60, $263-286$.

Hodgson, C. M. (2009). On the institutional foundations of law: The insufficiency of custom and private ordering. Journal of Economic Issues, $X L I I I(1), 143-165$

Jensen, M. C., \& Meckling, W. H. (1976). Theory of the firm: Managerial behavior, agency costs and ownership structure. Journal of Financial Economics (October), 3(4), 305-360.

Kasper, W., \& Streit, M. E. (1998). Institutional economics. Social order and public policy. Edward Elgar, Cheltenham UK Northampton MA USA.

Kim, K., \& Viswanathan, S. (2016) The experts in the crowd: The role of reputable investors in crowdfunding market, https://papers.ssrn.com/sol3/papers.cfm?abstract_id=2258243\#

Mapping (2015) Crowdfunding: Mapping EU markets and events study, study for the European Commission 2015, DOI: 10.2874/37466, http://ec.europa.eu/finance/general-policy/docs/crowdfunding/20150930-crowdfunding-study_en.pdf

Martens, B. (2016) An economic policy perspective on online platforms, institute for prospective technological studies, Digital Economy Working Paper 2016/05. JRC101501

Mayer, C. (1994). The assessment: Money and banking. Theory and evidence. Oxford Review of Economic Policy, 10(4), 1-13.

Milne, A., \& Parboteeah, P. (2016) The business models and economics of peer-to-peer lending, Research Report 17, European Credit Research Institute, Brussels.

Mollick, E. (2014). The dynamics of crowdfunding: An exploratory study. Journal of Business Venturing, 29, 1-16.

Morse, A. (2015) Peer-to-peer crowdfunding: Information and the potential for disruption in consumer lending, NBER Working Paper Series, National Bureau of Economic Research, Cambridge Massachusetts.

Nielsen, K. (2006). An institutional approach to transformation in central and Eastern Europe. In K. Nielsen (Ed.), Institutional change, values and learning. Cheltenham: Edward Elgar.

North, D. (1990). Institutions, institutional change and economic performance. Cambridge: Cambridge University Press.

North, D. (1995) Some fundamental puzzles in economic history/development, economic history, No. 9509001, EconWPA (http://ideas.repec.org)

North, D. (1997). Institutional Change: A Framework of Analysis. Voprosy Ekonomiki, 3, 6-17.

Oxera. (2015). Crowdfunding from an investor perspective. Brussels:Author. doi:10.2874/61896, http://ec.europa.eu/finance/finservicesretail/docs/fsug/papers/160503-study-crowdfunding-investor-perspective_en.pdf.

Parisi, F. (2004). Positive, normative and functional schools in law and economics. European Journal of Law and Economics, 18(No), 3.

Paschen, J. (2017). Choose wisely: Crowdfunding through the stages of the startup cycle. Business Horizons, 60, 179-188.

Potrafke, N. (2013). Evidence on the political principal-agent problem from voting on public finance for concert halls. Constitutional Political Economy, 24(3), 215-238.

Ramsay, I. (2015) Changing policy paradigms of EU consumer credit and debt regulation, in: S. Weatherill \& D. Leczykiewicz (eds.) The images of the Consumer in the EU Law. Hart, Bloomsbury: Hart.

Rochet, J.-C., \& Tirole, J. (2004) Two-sided markets. An overview, Massachusetts institute of technology, http://1web.mit.edu/14.271/www/rochet_tirole.pdf

Sharpe, S. A. (1990). Asymmetric information, bank lending, and implicit contracts: A stylised model of customer relationship. The Journal of Finance, XLV(4),1069-1087.

Shin, H. S. (2009). Securitisation and financial stability. Economic Journal, 119, 309-332.

Stiglitz, J. E., \& Weiss, A. (1992). Asymmetric information in Credit Markets and Its Implications for Macro-economics. Oxford Economic Papers, $44,694-724$.

Szanyi, M. (2016). The reversal of the privatization logic in central European transition economies. Acta Oeconomica, 66(1), 33-55.

Viotto Da Cruz, J. (2016). Beyond financing: Crowdfunding as an informational mechanism. Paris:Université Paris 13.

Viotto, J. (2015). Competition and regulation of crowdfunding platforms: A two-sided market approach. Digiworld Economic Journal, 99,33-50. $3 \mathrm{rd}$.

Wardrop, R., Zhang, B., Rau, R., \& Gray, M. (2015) Moving mainstream the european alternative finance benchmarking report, Cambridge Centre for Alternative Finance, University of Cambridge Judge Business School.

Williamson, O. (2000). The new institutional economics: Taking stock, looking ahead. Journal of Economic Literature, XXXVIII, 595-613.

Zhang, B., Wardrop, R., Ziegler, T., Lui, A., Burton, J., James, A., \& Garvey, K. (2016) Sustaining momentum. The 2nd European alternative finance industry report, Cambridge Centre for Alternative Finance, University of Cambridge Judge Business School. 
Zhang, J., \& Liu, P. (2012). Rational herding in microloan markets. Management Science, 58(5), 892-912.

Ziegler, T., Shneor, R., Garvey, K., Wenzlaff, K., Yerolemou, N., Hao, R., \& Zhang, B. (2018) Expanding horizons, The 3rd European alternative finance industry report, Cambridge Centre for Alternative Finance, University of Cambridge Judge Business School. 